University of Nebraska - Lincoln

DigitalCommons@University of Nebraska - Lincoln

Agronomy \& Horticulture -- Faculty Publications

Agronomy and Horticulture Department

1995

\title{
An Automated Plot Harvest System For Use With A Commercial Forage Harvester
}

Jeffrey F. Pedersen

University of Nebraska-Lincoln, jpedersen1@unl.edu

Kenneth J. Moore

lowa State University

Follow this and additional works at: https://digitalcommons.unl.edu/agronomyfacpub

Part of the Agricultural Science Commons, Agriculture Commons, Agronomy and Crop Sciences Commons, Botany Commons, Horticulture Commons, Other Plant Sciences Commons, and the Plant Biology Commons

Pedersen, Jeffrey F. and Moore, Kenneth J., "An Automated Plot Harvest System For Use With A Commercial Forage Harvester" (1995). Agronomy \& Horticulture -- Faculty Publications. 965. https://digitalcommons.unl.edu/agronomyfacpub/965

This Article is brought to you for free and open access by the Agronomy and Horticulture Department at DigitalCommons@University of Nebraska - Lincoln. It has been accepted for inclusion in Agronomy \& Horticulture -Faculty Publications by an authorized administrator of DigitalCommons@University of Nebraska - Lincoln. 


\section{AN AUTOMATED PLOT HARVEST SYSTEM FOR USE WITH A COMMERCIAL FORAGE HARVESTER}

\author{
Jeffrey F. Pedersen* and Kenneth J. MoORE
}

\begin{abstract}
This automated harvest system is based on minimal modification of currently available commercial forage harvesters. Using $6.8 \mathrm{~m}$ plots separated by $0.75 \mathrm{~m}$ alleys, a single operator can harvest, finely chop, and collect wet plot weights of forage sorghum [Sorghum bicolor (L.) Moench] or pearl millet [Pennisetum glaucum (L.) R. Br.] in $<1$ min per plot. Harvested material is deposited in a pile in the center of each plot. Subsamples for moisture and quality analysis can easily and safely be obtained from the pile.
\end{abstract}

$\mathrm{D}^{\mathrm{s}}$ ESIGNS are available for many small self-propelled flail-type forage harvesters for use in forage research programs (Allen et al., 1968; Buker, 1967; Collins et al., 1969; McCormick and Hoveland, 1971). While adequate for most grasses and legumes, these harvesters tend to knock down tall forages such as forage sorghum and sudangrass [Sorghum bicolor (L.) Moench], and often do not have adequate capacity for small plots of these forages. Most require samples to be physically placed in a bag or on a tarp and carried to scales for weighing.

A number of small self-propelled forage harvesters resembling commercial-scale harvesters are now in use in forage sorghum research (Swallow, 1967). Other designs are modified commercial pull-type forage harvesters with catch baskets and scales. These modifications not only make the machine unsuitable for other farm uses, but also require personnel to ride on the harvester to read the scale and dump the catch basket (Robert Klein, 1990, personal communication).

These systems are useful, but a harvest system based on currently available commercial forage harvesters requiring minimal modification was needed. This allows use of equipment for other research or general farming operations. For safety reasons, this system does not require personnel to ride on the harvester. A description of such a system and its performance parameters are described below.

\section{Equipment Design}

The automated harvest and weighing system consists of a stock tractor, a slightly modified commercial forage harvester, a detachable semi-mounted weigh bucket equipped with load cells, and a data control center (indicator). The entire system is shown in Fig. 1.

J.F. Pedersen, USDA-ARS, Dep. of Agronomy, Univ. of Nebraska, Lincoln, NE 68583-0937; K.J. Moore, Dep. of Agronomy, lowa State Univ., Ames, IA 50011. Mention of firm names or trade products does not imply that they are endorsed or recommended by the USDA-ARS or the Univ. of Nebraska over other firms or products not mentioned. Joint contribution of the USDA-ARS, and the Nebraska Agric. Res. Div., Univ. of Nebraska. Journal Series no. 10668. Received 20 May 1994. *Corresponding author (Email: agrol37@unlvm.unl.edu).

Published in Agron. J. 87:605-607 (1995).

\section{Tractor Requirements}

The tractor must be configured to meet harvester specifications. For light-duty harvesters, a minimum of $41 \mathrm{~kW}$ ( 55 horsepower) is needed. The tractor must be equipped with two hydraulic systems to operate two sets of hydraulic cylinders (harvester head height adjustment, and weigh bucket door operation). Additionally, the tractor must be equipped with a twostage clutch that will allow the operator to disengage power to the tractor wheels and stop forward motion while maintaining constant power to the power take off.

\section{Harvester Modifications}

A New Holland Model 718 (Ford New Holland, New Holland, PA) with a one-row head was used. The addition of two hitch mount plates (Fig. 2) to the harvester frame or axle, and a detachable spout to direct the harvester discharge downward into the weigh bucket, are the only harvester modifications required.

\section{Weigh Bucket Design}

The weigh bucket consists of a frame, and a hydraulically operated bucket mounted rigidly to the frame on four WeighTronix (Weigh-Tronix, Fairmont, MN) weigh-bars (Fig. 2). The bottom of the weigh bucket is two swinging doors operated hydraulically from the tractor. The hydraulic components are attached directly to the weigh bucket. The weigh bucket attaches to the harvester via the hitch mount plates (Fig. 2) with two steel pins that act as a hinge and allow the system to flex on uneven terrain. The rear of the weigh bucket is supported by a single trailing caster wheel. The load cells are connected to a tractor mounted Weigh-Tronix 3000 indicator, which integrates data from the four weigh-bars and produces digital read-out of plot weights, as well as RS-232 (serial interface) output of the data if desired. Sensitivity can be set as low as $\pm 50 \mathrm{~g}$, and a motion indicator is provided to inform the operator when a stable weight has been obtained. The system can be tared after each weight measurement.

All safety recommendations made by the forage chopper manufacturer should be followed. Since the bucket doors are hydraulically operated and the discharge from the chopper is at relatively high velocity, no one should be permitted on or near the bucket component when in operation. Additionally, the bucket should be labeled DANGER and STAND CLEAR with commercially available placards. The door edges and other moving parts should be painted bright red or labeled with commercially available yellow and black striped placards. The tractor should be shut off prior to adjustment or service, or whenever anyone may come into physical contact with the weigh bucket. Due to the instability and weight of the weigh bucket, a minimum of three people are needed to attach or separate the weigh bucket from the forage harvester. If it is anticipated that three people will not be available for these operations, crank-down legs should be installed to stabilize and support the weigh bucket during these operations.

\section{Performance and Limitations}

Using $6.8-\mathrm{m}$ plots separated by $0.75-\mathrm{m}$ alleys, a single operator can harvest and collect forage sorghum wet plot weights in $<1 \mathrm{~min}$. The system has also been used on pearl millet with excellent results. When the harvester is stopped at the end of the plot and the weigh bucket is emptier, the plot material is deposited in the center of the plot.

Abbreviations: rpm, revolution(s) per minute. 


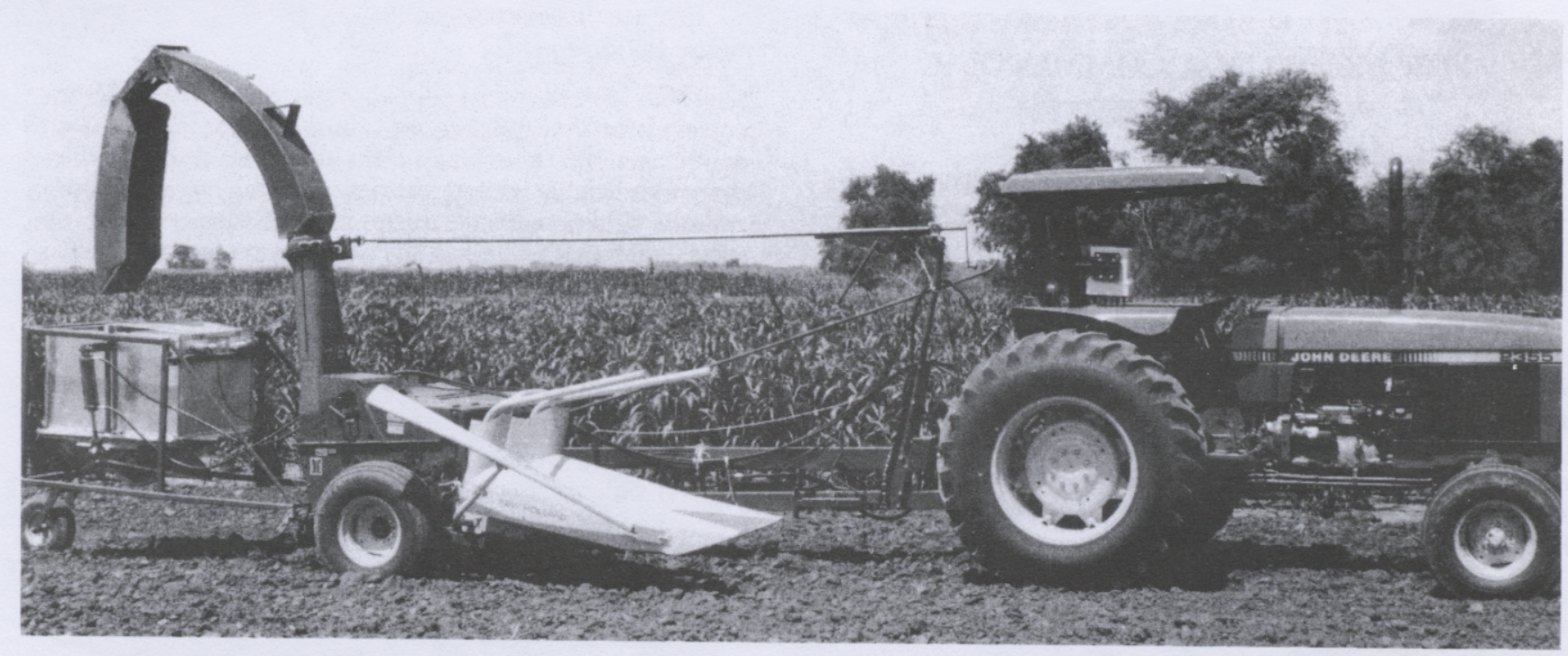

Fig. 1. Complete automated plot harvesting system.

Subsamples for moisture and quality analysis can easily and safely be obtained from the pile of chopped forage by other personnel. If experimental protocol does not allow the chopped forage to be deposited on the plot, forage from several plots can be accumulated in the weigh bucket and dumped outside of the plot area. Individual plot weights can be obtained by taring the scale to zero at the end of each plot.

Motion caused by wind is not a problem when sensitivity is set at $\pm 50 \mathrm{~g}$, except under very gusty conditions. The force exerted on the weigh bucket by air flow from the harvester discharge spout is constant and can be tared to zero by the operator if constant tractor rpm's are maintained on the tractor and the power take-off clutch is engaged while taring and weighing.

Experimental design and field plot layout is important for optimizing operation of this system. Since pull-type commercial forage harvesters are offset to the right of the tractor, it is necessary to harvest from the outside rows, in a circular fashion. It is also necessary to have very large borders or headlands ( $15 \mathrm{~m}$ minimum) at the end of the experiment to allow turning. This harvest system is not

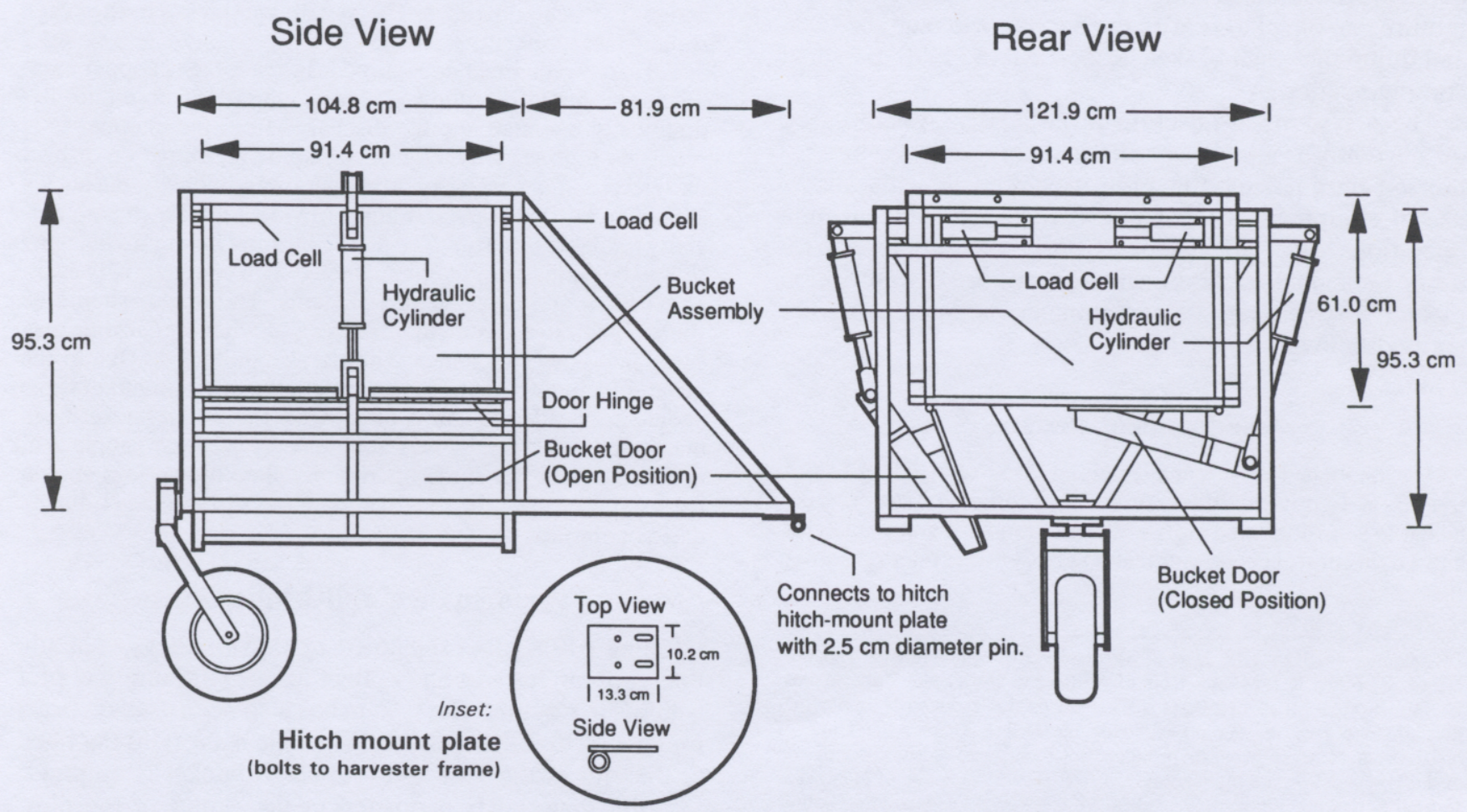

Fig. 2. Weigh bucket component, side and rear views. 
suited for experiments in which some plots are harvested at different physiological stages, or on different calendar days.

\section{Blueprints and Cost}

Complete blue prints are available from the corresponding author upon request. A cost estimate for construction of the weigh bucket, including labor and all materials except the load cells and indicator is $\$ 5000$. Materials cost excluding the load cell and indicator is estimated at $\$ 2000$ (estimates provided by Precision Machine, Lincoln, NE). Addition of the scale and load cells brings the total estimated cost to $\$ 7000$, excluding the forage harvester and tractor.

\section{Acknowledgments}

We would like to thank Dr. Robert Klein, DeKalb Genetics, Glenvil, NE, for inviting us to view their forage harvester. Notes and sketches taken provided the basic framework from which this automated system was developed.

\section{References}

Allen, R.J., T.W. Casselmann, and F.H. Thomas. 1968. An improved forage harvester for experimental plots. Agron. J. 60:584-585.

Buker, R.J. 1967. Forage plot harvester. Agron. J. 59:203-204.

Collins, K.L., C.L. Rhykerd, and C.H. Noller. 1969. A self-propelled experimental plot forage harvester. Agron. J. 61:338-339.

McCormick, R.F., and C.S. Hoveland. 1971. The Auburn small-plot forage harvester. Agron. J. 63:951-952.

Swallow, C. 1967. Self-propelled plot forage harvester. Agron. J. 59:609-610. 